\title{
ECOLOGICAL LIFE HISTORY OF PELTOPERLA TARTERI (PLECOPTERA:PELTOPERLIDAE) FROM BIG HOLLOW OF PAINT CREEK, FAYETTE COUNTY, WEST VIRGINIA*
}

\author{
By Kimberly K. Ruggles and Donald C. TARTer \\ Department of Biological Sciences, Marshall University, \\ Huntington, West Virginia 25755
}

\section{INTRODUCTION}

The various species of stoneflies within given stream biotypes have temporarily segregated their life histories and partitioned their food and space resources so that they play a vital role in the energy economy and production of headwater streams (Stewart and Stark 1988). Overall the knowledge of immature stages of stoneflies is lacking. The precise life histories, trophic interactions, growth and development, spatial distribution, and behavior of naiads are well known for less than 5\% of the estimated 1,800 world species (Stewart and Stark 1988).

The objectives of this study were: (1) to describe the life history of Peltoperla tarteri Stark and Kondratieff, a newly described species, and (2) to investigate the role environment plays in this life history.

\section{TAXONOMY AND DISTRIBUTION}

The family Peltoperlidae belongs to the suborder Filipalpia and is one of the smallest families of Plecoptera, comprising 6 genera and 18 described species (Stewart and Stark 1988). Stark and Kondratieff (1987) described Peltoperla tarteri from Virginia and West Virginia; the type-locality was Big Hollow of Paint Creek, Fayette County, West Virginia.

Peltoperla tarteri is a Nearctic species found in the eastern United States. According to Stark and Kondratieff (1987), the distribution of $P$. tarteri ranges broadly in the Blue Ridge, Ridge and Valley and Appalachian Plateau physiographic provinces of

${ }^{*}$ Manuscript received by the editor January 28, 1991. 
Virginia and West Virginia. It has been collected from Kanawha, Fayette, and Wyoming counties in West Virginia, and from Craig, Floyd, Giles, Greene, Nelson, and Patrick counties in Virginia.

\section{DESCRIPTION OF STUdy AREA}

The Peltoperla tarteri population was studied at Big Hollow, a small first order tributary of Paint Creek in the Kanawha River Basin. Big Hollow is 0.9 mile $(1.5 \mathrm{~km})$ in length from source to mouth and falls 740 feet $(226 \mathrm{~m})$; the drainage area is 0.5 square miles (1.3 sq km). The study site at Big Hollow was located along the West Virginia Turnpike 1.7 miles NW of the Mossy interchange. The elevation of this area is $1400 \mathrm{ft}(427 \mathrm{~m})$. Big Hollow cuts through a deep ravine. The stream's rocky substratum, composed mainly of sandstone, creates an uneven streambed that is frequently interrupted by small waterfalls. The dense overhead canopy of cove hardwoods allows little light penetration to the stream during the summer months.

\section{MATERIALS AND METHODS}

Peltoperla tarteri naiads were collected monthly from November 1988 to October 1989. Leaf packs were placed in white metal pans and searched for naiads. Approximately 20-25 naiads were removed from the packets using forceps and were placed in vials containing $70 \%$ ethanol. In the absence of leaf packs (June through August), the naiads were collected from the submerged surface of rocks. Relative abundance of naiads was determined by dividing the number of naiads collected by the time spent collecting (45-60 minutes).

During each monthly collection, water chemistry was tested using a Hach Ecology Testing Kit, Model AL-36B. Parameters measured included dissolved oxygen $(\mathrm{mg} / \mathrm{L})$, carbon dioxide $(\mathrm{mg} / \mathrm{L})$, alkalinity $\left(\mathrm{mg} / \mathrm{L} \mathrm{CaCO}_{3}\right)$, total hardness $\left(\mathrm{mg} / \mathrm{L} \mathrm{CaCO}_{3}\right)$, and $\mathrm{pH}$. The water temperature was measured using a Celsius thermometer.

The stream was searched for naiadal exuviae every four to five days from May 1989 to July 1989. Exuviae were found on the stream banks and on the exposed and submerged surfaces of rocks. They were counted and preserved in $70 \%$ ethanol. 
Attempts were made to collect adult $P$. tarteri specimens each time the stream was searched for exuviae. A net was used to sweep the vegetation along the stream banks to trap the adults during late morning and early afternoon. Only two adults were collected in this manner, and they were preserved in $70 \%$ ethanol. In an earlier investigation, Kirchner (pers. comm.) collected adults by sweeping the vegetation from 0700 to 0900 hours. In May 1989, 15 naiads were collected and transported to the laboratory for rearing to adults.

In the laboratory, Peltoperla naiads were measured using an ocular micrometer in a Bausch and Lomb dissecting microscope, and the increments of the grid were calibrated using an American Optical stage micrometer. The body lengths of the naiads were determined from the anterior tip of the head to the base of the caudal filaments. Using these measurements, a length frequency histogram was constructed using increments of two millimeters for body length. Head width was measured at the widest portion of the head and the data obtained were used to construct a size frequency distribution using increments of $0.1 \mathrm{~mm}$.

Monthly growth rates were determined by calculating the percent increase in growth from one month to the next month. A population range diagram, using mean head width, range, and two standard errors of the mean, was constructed monthly to indicate head width variation throughout one year's growth. Any significant differences between means were determined by comparing the overlap of the two standard errors of the mean $(<0.05$ confidence level).

To sex the individual naiads, the hind margin of the eighth abdominal sternite was observed. The presence of a small median notch was characteristic of a female naiad, whereas the absence of the notch indicated a male naiad. The notch was not observable in the more immature naiads. A chi-square analysis was performed to determine if the sex ratio deviated from the $1: 1$ ratio at the 0.05 confidence level.

Five naiads from each month were selected for foregut analysis. The relatively largest naiads were selected and measured (body length and head width) using the ocular micrometer. After making a ventral mid-thoracic incision, the foregut was removed from the thorax using a stainless steel probe. An Eppendorf 500 pipet was 
used to transfer the gut contents to a vial containing 3 milliliters of water. This solution was mixed thoroughly with seven drops of iodine solution and one milliliter was transferred to a SedgwickRafter cell using a pipet. This cell was examined under a Bausch and Lomb Galen phase contrast microscope containing a Whipple grid under $200 \times$ magnification. Ten grids were randomly selected and the gut contents were identified as plant detritus, mineral detritus, diatoms, desmids, or filamentous green algae. This milliliter of fluid was replaced with a second milliliter of fluid from the same month and the above procedure was followed. The relative abundance of the five food categories was determined by a percentage composition of each food category in 100 squares/grid.

Fecundity was determined by direct count. Eggs from 13 adults were counted in a petri dish under a Bausch and Lomb dissecting microscope. Regression analysis was used to determine the relationship between total body length and number of eggs produced. A correlation coefficient ( $r$ ) was calculated to determine the strength of the relationship. The diameter and length of 50 eggs from each female was measured to the nearest $0.01 \mathrm{~mm}$ using an ocular micrometer in the dissecting microscope.

\section{Results AND Discussion}

\section{Stream environment}

Dissolved oxygen ranged from 10.0 to $15 \mathrm{mg} / \mathrm{L}(\overline{\mathrm{X}}=11.4$ $\mathrm{mg} / \mathrm{L})$. Carbon dioxide ranged from 5.0 to $30 \mathrm{mg} / \mathrm{L}(\bar{X}=7.5$ $\mathrm{mg} / \mathrm{L}$ ). The mean alkalinity value was $1.6 \mathrm{mg} / \mathrm{L} \mathrm{CaCO}$ (range, 1-2 mg/L $\mathrm{CaCO}_{3}$ ). Total hardness ranged from 3.0 to $19.0 \mathrm{mg} / \mathrm{L}$ $\mathrm{CaCO}_{3}(\overline{\mathrm{X}}=6.8 \mathrm{mg} / \mathrm{L})$. The mean hydrogen ion concentration $(\mathrm{pH})$ was 6.9 with a range of 6.3 to 7.2. Monthly water temperature varied from 3.0 C (December) to 19.0 (July) ( $\overline{\mathrm{X}}=11.2 \mathrm{C}$ ). Detailed water analysis can be found in Ruggles (1990).

\section{Habitat observations}

The naiads of Peltoperla tarteri congregated on leaf packs located in riffle areas of the stream. The amount of compaction of leaves seemed to influence the distribution of the naiads as they were more abundant in the more loosely packed leaves. After emergence of adults the small naiads were found exclusively on the submerged surfaces of rocks. Overall, naiads were found primarily 
in the leaf packets except for the month of August when the packs were scarce.

\section{Length frequency histograms}

Length frequency analysis of the naiads indicated a univoltine life cycle (Fig. 1). The smallest naiad, $1.18 \mathrm{~mm}$, was found in June, while the largest naiad, measuring $10.88 \mathrm{~mm}$, was found in May. Naiads began hatching in late May through mid June, grew more rapidly through October, and then more slowly through the winter months. There appears to be no egg diapause. The first sign of adult emergence was seen in late May (Fig. 2) and there was an increase in relative abundance of naiads in June (Fig. 1).

Claassen (1931) suggested a semivoltine cycle for $P$. arcuata Needham for populations near Ithaca, New York. Several years later, Miller and Kovalak (1979) suggested a univoltine life cycle for the same species in the streams of Pennsylvania. The naiads apparently hatched without egg diapause in July, grew slowly until October then more rapidly through the winter, and adults emerged in late June to early July. Huryn and Wallace (1987) suggested a semivoltine life cycle for Tallaperla maria (Needham and Smith) and Viehoperla ada (Needham and Smith). Also, a semivoltine life cycle was suggested for Sierraperla cora (Needham and Smith) with an extended emergence period in spring habitats (Stewart and Stark 1988).

\section{Naiadal exuviae}

Attempts were made to collect exuviae on May 12,16, 19, and 24 , but none were recovered. The first sign of emergence was seen on May 29, 1989, when two exuviae were recovered (Fig. 2). Water temperature at this time was $13.5 \mathrm{C}$. The temperature ranged from 10.0 on May 12 to $12.0 \mathrm{C}$ on May 19. The largest number of exuviae (48) was taken on June 3. Twenty-seven exuviae were found on June 14, but high water through June 22 interfered with the collections. Seven exuviae were found on June 23, but further attempts through July 23 were unsuccessful; therefore, weekly examination for exuviae ceased. These data suggest that emergence for $P$. tarteri occurred between late May and late June (13.5 to $16.0 \mathrm{C}$ ) which corroborate the length frequency data for a univoltine life cycle. 


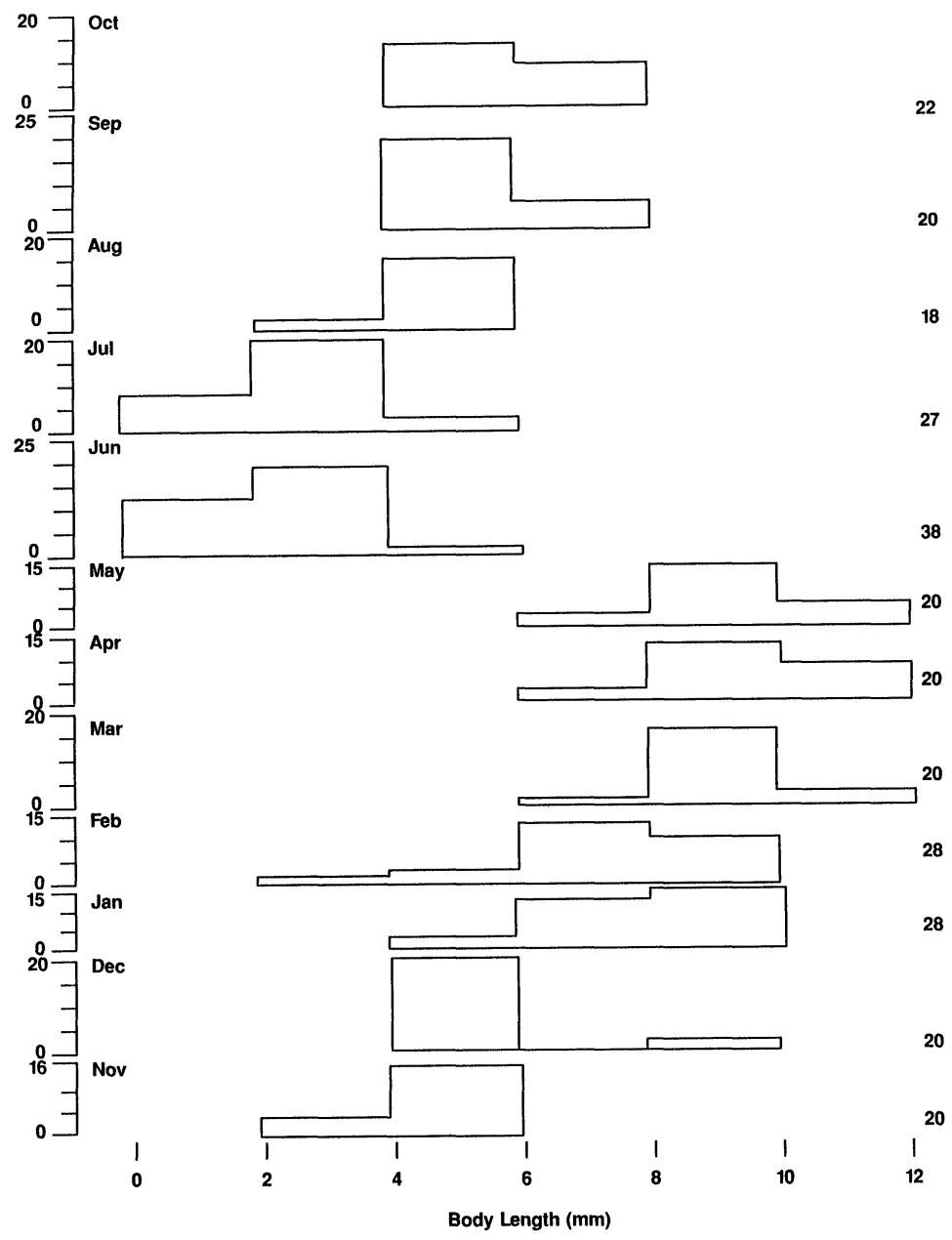

Figure 1. Length frequency distribution showing monthly body length of Peltoperla tarteri. 

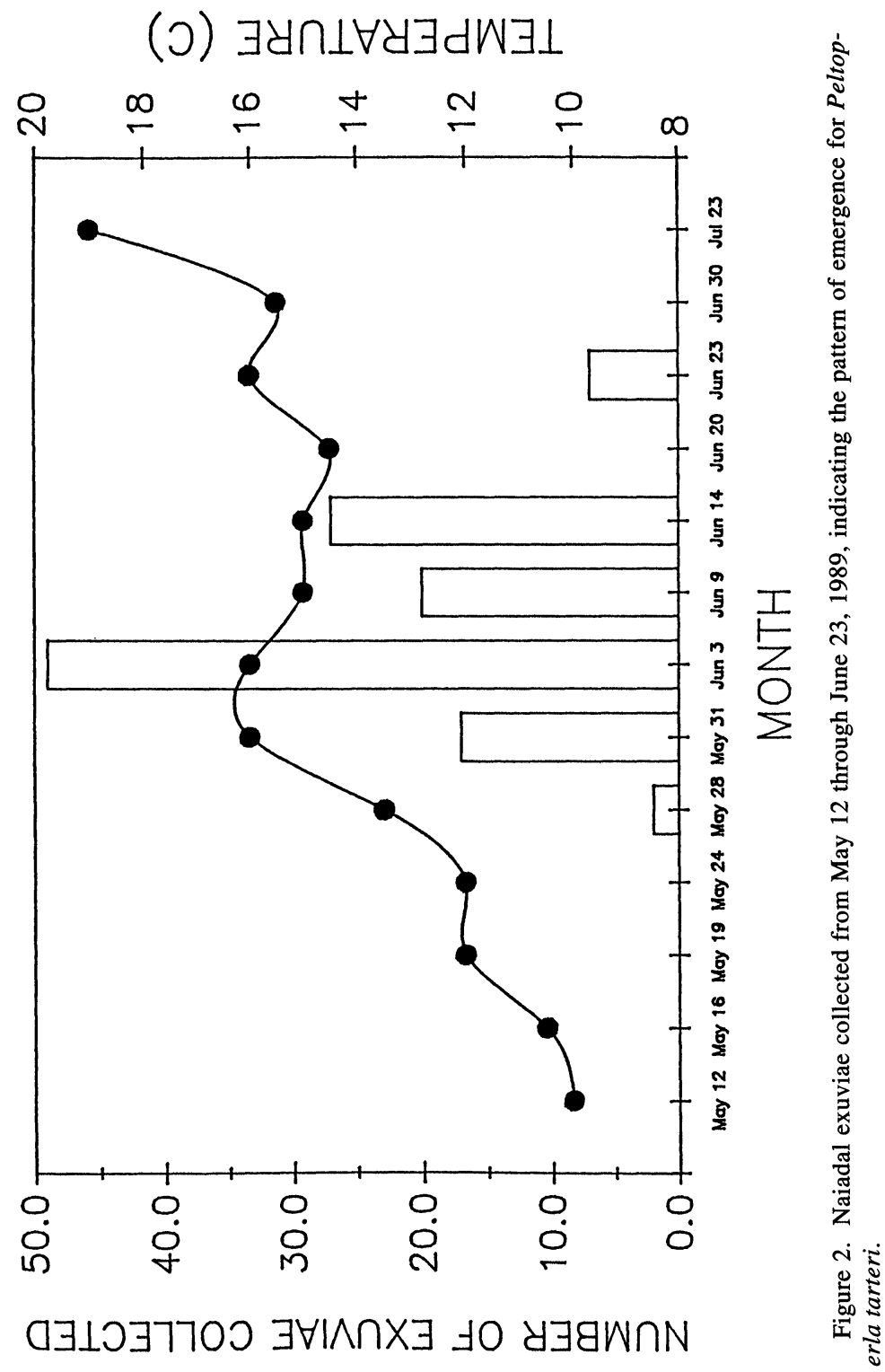


\section{Growth}

Population range diagrams demonstrate the monthly progression of head width sizes during the study period (Fig. 3). The largest amount of growth occurred between June and July (58.18\%). The largest decrease in size occurred between May and June (-57.94\%). This decrease corresponds with the month following a period of emergence and further supports a univoltine life cycle.

Significant growth occurred, based on amount of overlap between two standard errors of the mean in the population range diagrams, between June and July, and between July and August. Naiads undergo the majority of their growth from June through November (Fig. 3). Water temperature during these months ranged from 16 to $19 \mathrm{C}$. Thereafter, the naiads showed little growth until after emergence in may and June. Growth reduction could be due to the lower temperatures (ranging from $3 \mathrm{C}$ in December to 13.5 $\mathrm{C}$ in May). Thus, temperature appears to play an important role in the life cycle of the naiads.

\section{Sex ratio}

A chi-square test was applied to 93 females and 104 males. The difference was not significant at the 0.05 confidence level.

\section{Foregut analysis}

Peltoperla naiads are shredder-detritivores; the major component of the diet is plant detritus $(81.8 \%)$ (Table 1). Mineral detritus and diatoms composed 17.71 and 0.47 percent, respectively, of the diet. The allochthonous organic material would offer the insects a carbohydrate supply which is commonly used as the major source of energy, and may also be converted into fats for energy storage or into amino acids. The mineral detritus (ash content) of the diet is of little nutritional value; however, it does serve as a source of essential salts and trace elements (Resh and Rosenberg 1984). The cytoplasm in diatoms is rapidly digested by insects, making them a good food source. However, the low percent composition of diatoms indicates that these organisms may not be an essential component of the diet. Diatom genera identified were Navicula, Synedra, and Meridion. Navicula and Synedra were the most common diatoms present from April through August. Meridion was found only in February. The presence of diatoms in the diet in early spring and summer months corresponds to the decrease in 


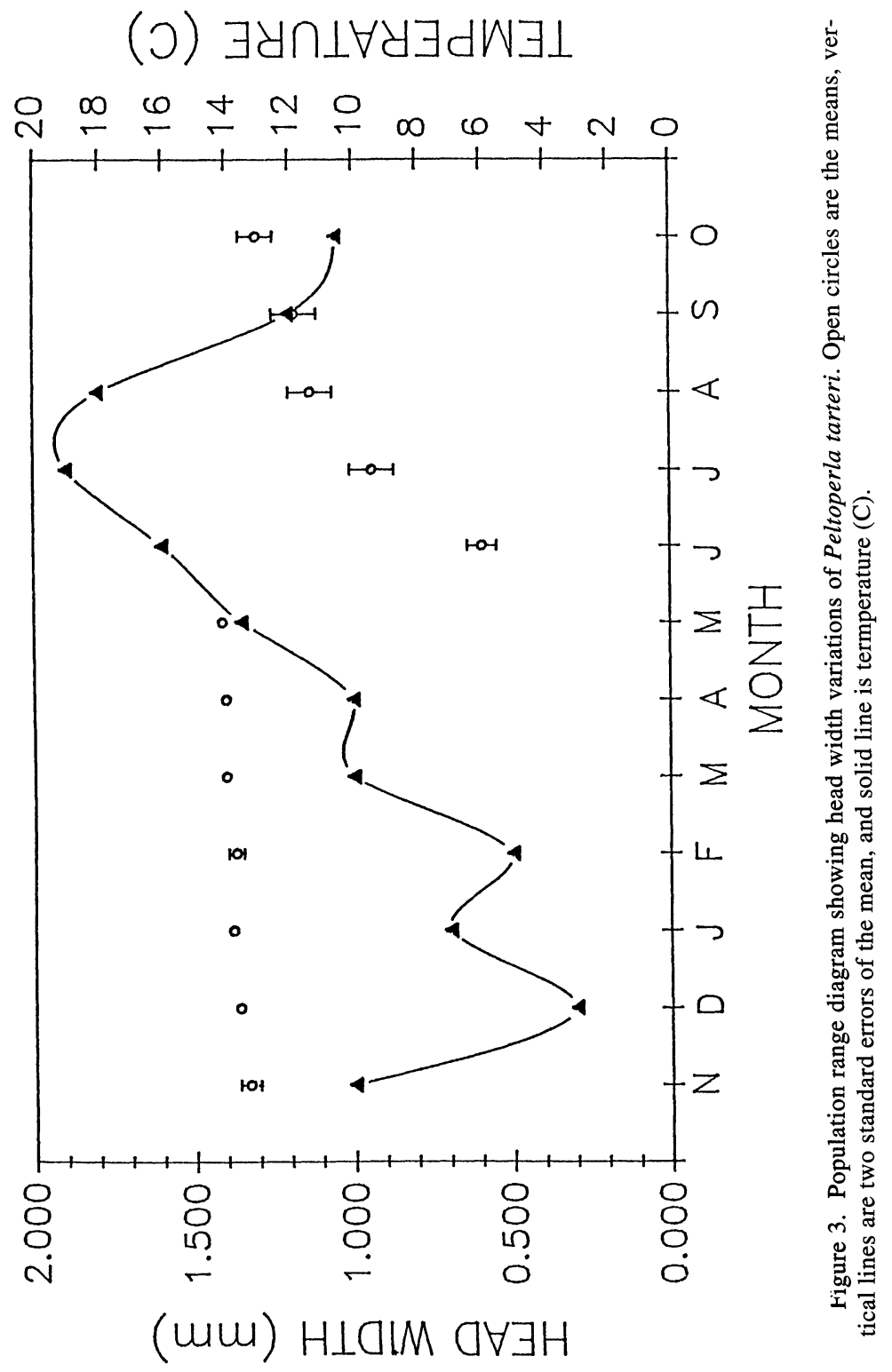


Table 1. Percentage composition of foregut contents of naiadal Peltoperla tarteri, at Big Hollow, November 1988-October 1989.

\begin{tabular}{cccc}
\hline Month & Plant Detritus & Mineral Detritus & Diatoms \\
\hline Nov & 90.10 & 9.90 & 0.00 \\
Dec & 87.21 & 12.79 & 0.00 \\
Jan & 79.00 & 21.00 & 0.00 \\
Feb & 80.85 & 17.82 & 1.33 \\
Mar & 77.71 & 22.29 & 0.00 \\
Apr & 82.44 & 17.04 & 0.52 \\
May & 83.00 & 16.20 & 0.80 \\
Jun & 78.26 & 21.32 & 0.42 \\
Jul & 74.47 & 24.43 & 1.10 \\
Aug & 71.23 & 27.32 & 1.45 \\
Sep & 87.21 & 12.79 & 0.00 \\
Oct & 90.41 & 9.59 & 0.00 \\
\hline MEAN & 81.82 & 17.71 & 0.47 \\
\hline
\end{tabular}

available plant detritus in the stream due to deterioration of the plant material and flushing of the headwater streams by spring storms.

With regard to season, the diet of $P$. tarteri naiads is fairly uniform throughout the year (Fig. 4); plant detritus dominated all seasons. However, during the months of June, July, and August, there was a decrease in plant detritus consumed. The naiads began hatching in May and were found exclusively on the submerged surfaces of rocks during the months of May and June. Leaf packs were scarce in the stream during August; therefore, naiads were found primarily on the rock surfaces. From September through May, the naiads were once again found in the leaf packets.

\section{Eclosion}

Emergence of adults occurred between May 31 and June 15, with the water temperature ranging from 19 to $25 \mathrm{C}$. During emergence the naiad crawled onto a rock or up the styrofoam container and a dorsal split occurred in the exoskeleton after which the adult made its way out. The adult remained stationary while the wings and body structures hardened and dried, then crawled or flew away. 


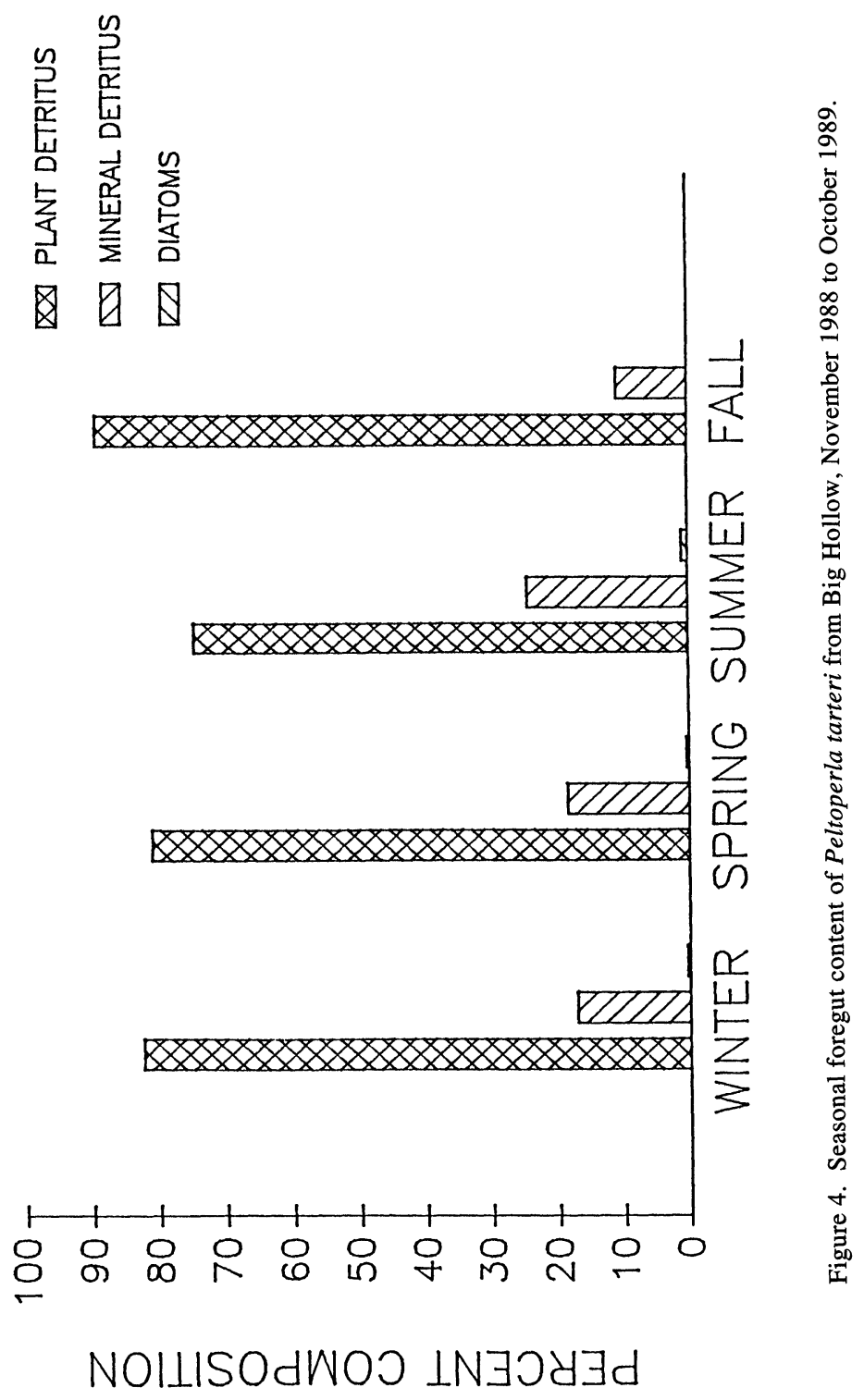




\section{Fecundity}

The ovaries of 13 adults were dissected from the body cavity. The mean number of eggs was 138 with a range of 50 to 249 . The mean body length of the female was $10.37 \mathrm{~mm}$ with a range of 8.18 to $12.23 \mathrm{~mm}$. A positive correlation of 0.84 was calculated for female body length versus number of eggs (Fig. 5). This correlation agrees with previous studies conducted with several species of aquatic insects by Sweeney and Vannote (1978).

Egg size

Stark and Kondratieff (1987) described the eggs of Peltoperla tarteri as spherical to slightly ovoid, collar lacking, micropyles present, and the chorionic surface finely punctate giving a rough surface appearance. In the Big Hollow adult females, the length and width of 645 eggs were determined. The mean length of the eggs was $0.29 \mathrm{~mm}$ with a range of 0.14 to $0.40 \mathrm{~mm}$. The mean width was $0.28 \mathrm{~mm}$ with a range of 0.14 to $0.40 \mathrm{~mm}$.

\section{SUMMARY}

An ecological life history investigation was conducted on Peltoperla tarteri from Big Hollow, Fayette County, West Virginia, from November 1988 to October 1989. A total of 281 naiads was collected with the highest relative abundance occurring in June 1989. Mature naiads were consistently found feeding on leaf packs located in flowing areas of the stream while the young naiads were found on the submerged surfaces of rocks. Naiadal exuviae were recovered from May 28 to June 23 (13.5 to $16.0 \mathrm{C}$ ); the largest number of exuviae (48) was taken on June 3, 1989. Length frequency distributions indicate a univoltine life cycle with adult emergence beginning in late May and continuing to late June. The greatest percentage (58.2) of naiadal growth occurred between June and July. A sex ratio of 1:1 was observed in P. tarteri naiads. Monthly foregut analysis indicates that naiads are detritivores with $81.8 \%$ of their diet consisting of plant detritus. The diet was also composed of mineral detritus $(17.7 \%)$ and diatoms $(0.47 \%)$. Direct egg counts ranged from 50 to 249 eggs/female with a mean of 138 . A correlation coefficient of 0.84 was calculated for female body

Figure 5. (Facing page.) Regression line of body length and number of eggs of adult Peltoperla tarteri. 


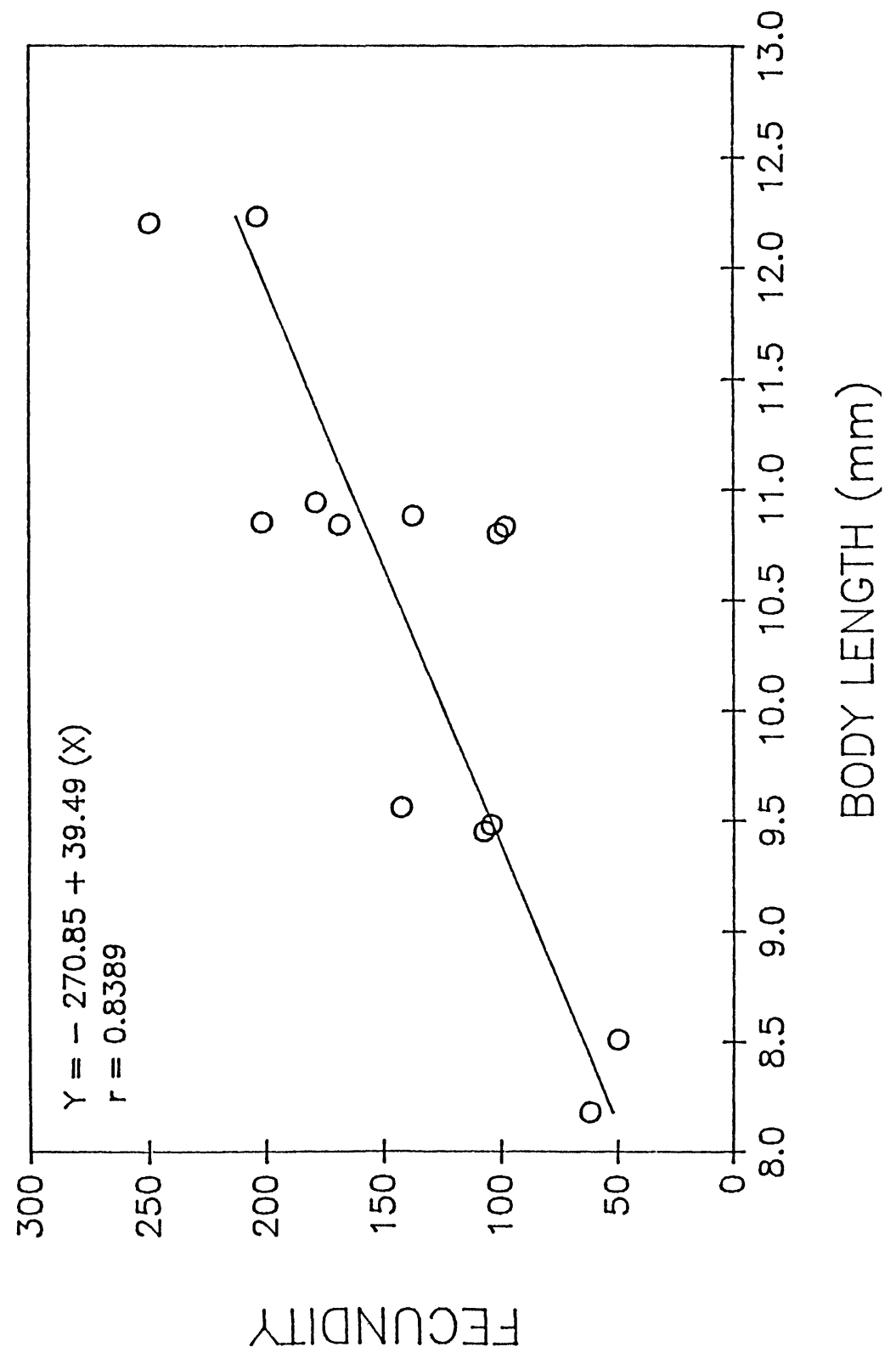


length versus fecundity. Mean egg measurements were $0.29 \mathrm{~mm}$ in length and $0.28 \mathrm{~mm}$ in width.

\section{ACKNOWLEDGEMENTS}

The authors are especially grateful to the following persons for help in this investigation: Dean Adkins, Lisa Burgess, Jeff Byard, Ralph Kirchner, and Thomas Weaks. Special thanks to Lu Ann South for typing the manuscript. This investigation was made possible through the Lemotto Smith-John Goodno Fellowship in aquatic biology at Marshall University.

\section{Literature Cited}

Claassen, P. W.

1931 Plecoptera nymphs of America (north of Mexico). Thomas Say Foundation 3: 1-199.

Huryn, A. D., AND J. B. Wallace

1987 The exopterygote insect community of a mountain stream in North Carolina, USA: life histories, production, and functional structure. Aquatic Insects 9(4): 229-251.

Miller, D. E., AND W. P. KovalaK

1979 Distribution of Peltoperla arcuata Needham (Ins., Plecoptera) in a small woodland stream. Int. Rev. Hydrobiol. 64: 795-800.

RESH, V. H., AND D. M. ROSENBERG

1984 The ecology of aquatic insects. Praeger Publishers, New York. $1-625 \mathrm{pp}$.

RUGGLES, K. K.

1990 Ecological life history, including laboratory respiratory investigation, of Peltoperla tarteri Stark and Kondratieff from Big Hollow of Paint Creek, Fayette County, West Virginia (Plecoptera:Peltoperlidae). Unpubl. Master's thesis, Marshall Univ., Huntington, WV. 73 pp.

StARK, B. P., AND B. C. KondratiefF

1987 A new species of Peltoperla from eastern North America (Plecoptera: Peltoperlidae). Proc. Entomol. Soc. Wash. 89: 141-146.

SteWART, K. W., AND STARK, B. P.

1988 Nymphs of North American Stonefly Genera (Plecoptera). The Thomas Say Foundation XII:1-460.

SWEENEY, B. W., AND R. L. VANNOTE

1978 Size variation and distribution of hemimetabolous aquatic insects: two thermal equilibrium hypotheses. Science 200: 44-46. 

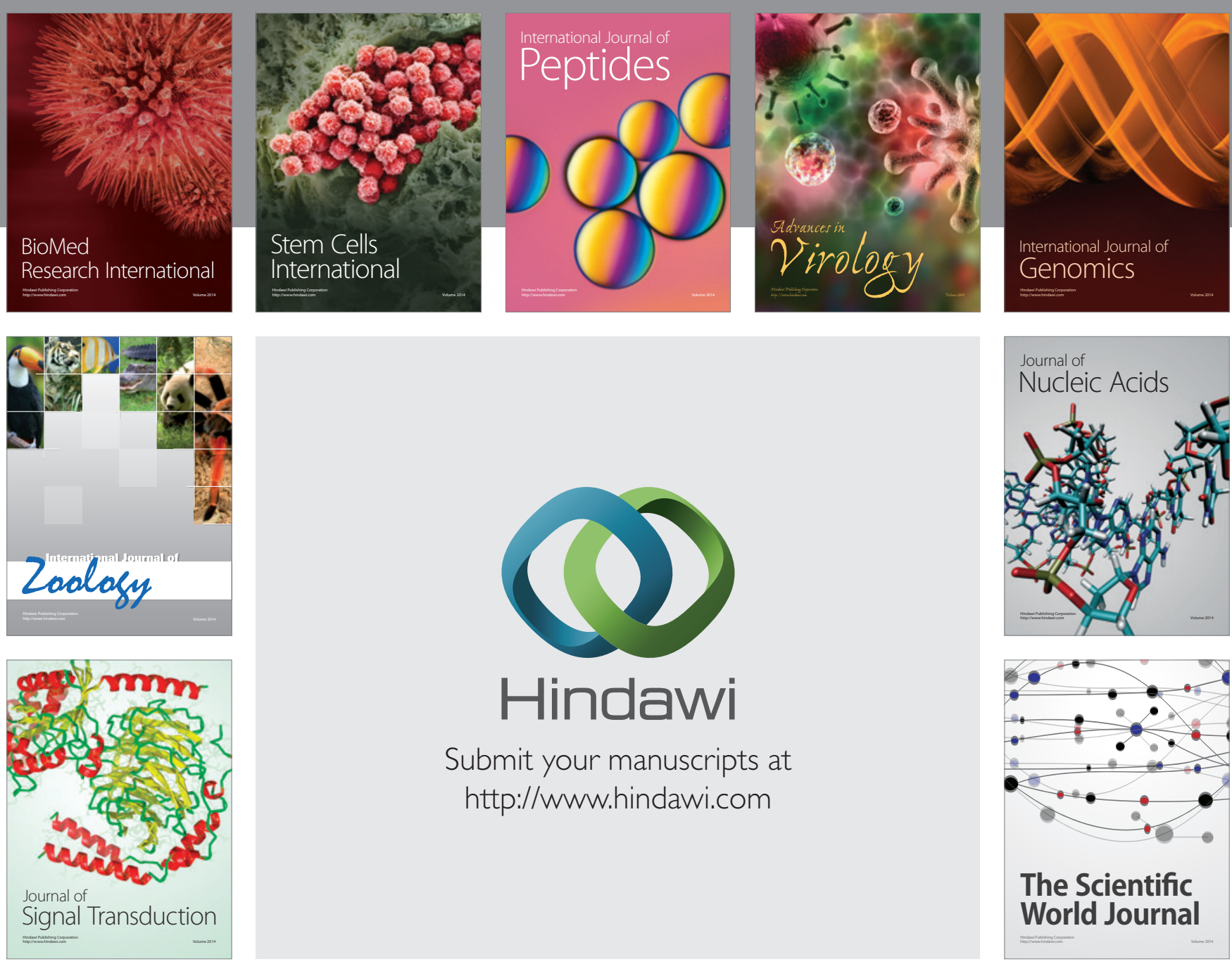

Submit your manuscripts at

http://www.hindawi.com
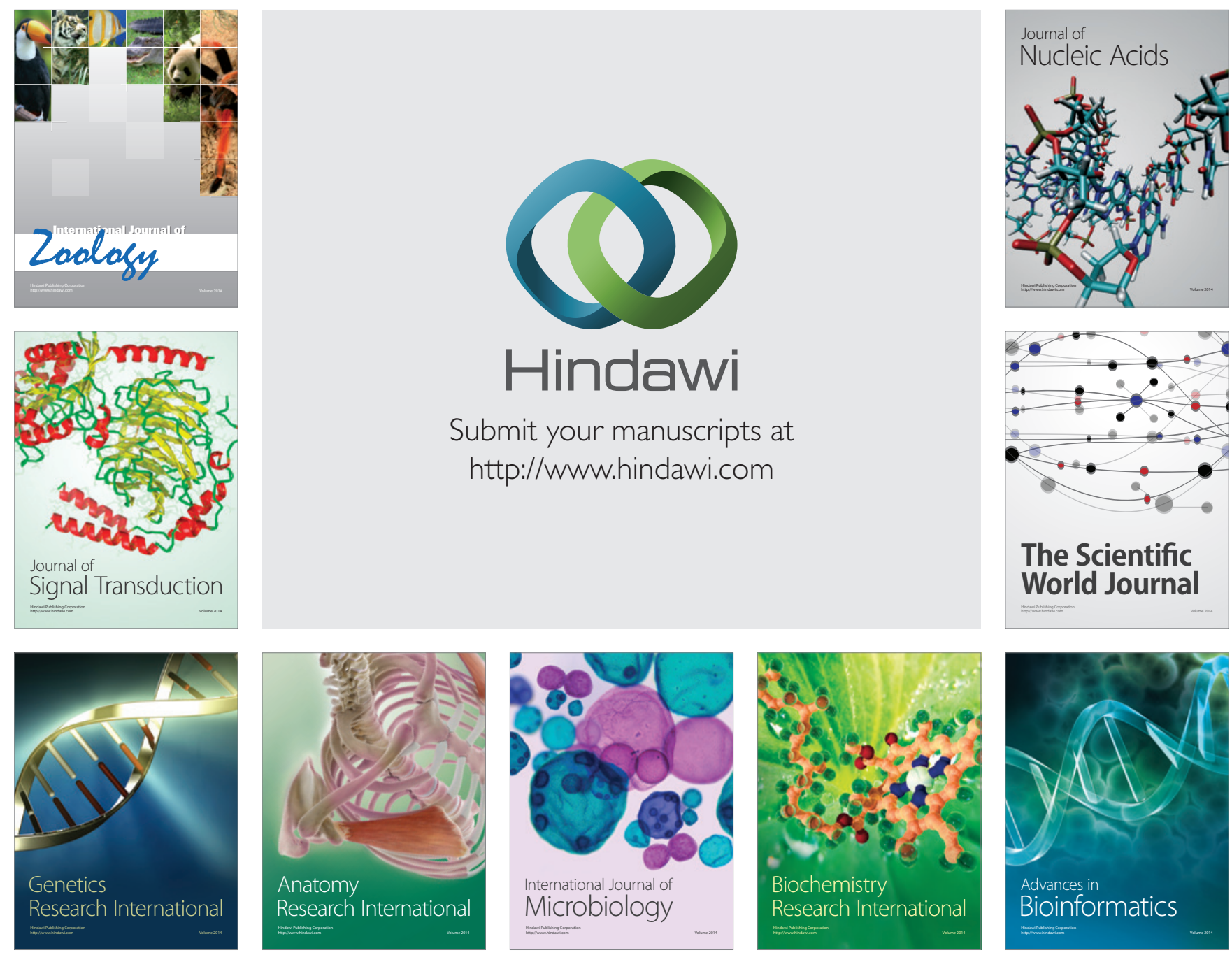

The Scientific World Journal
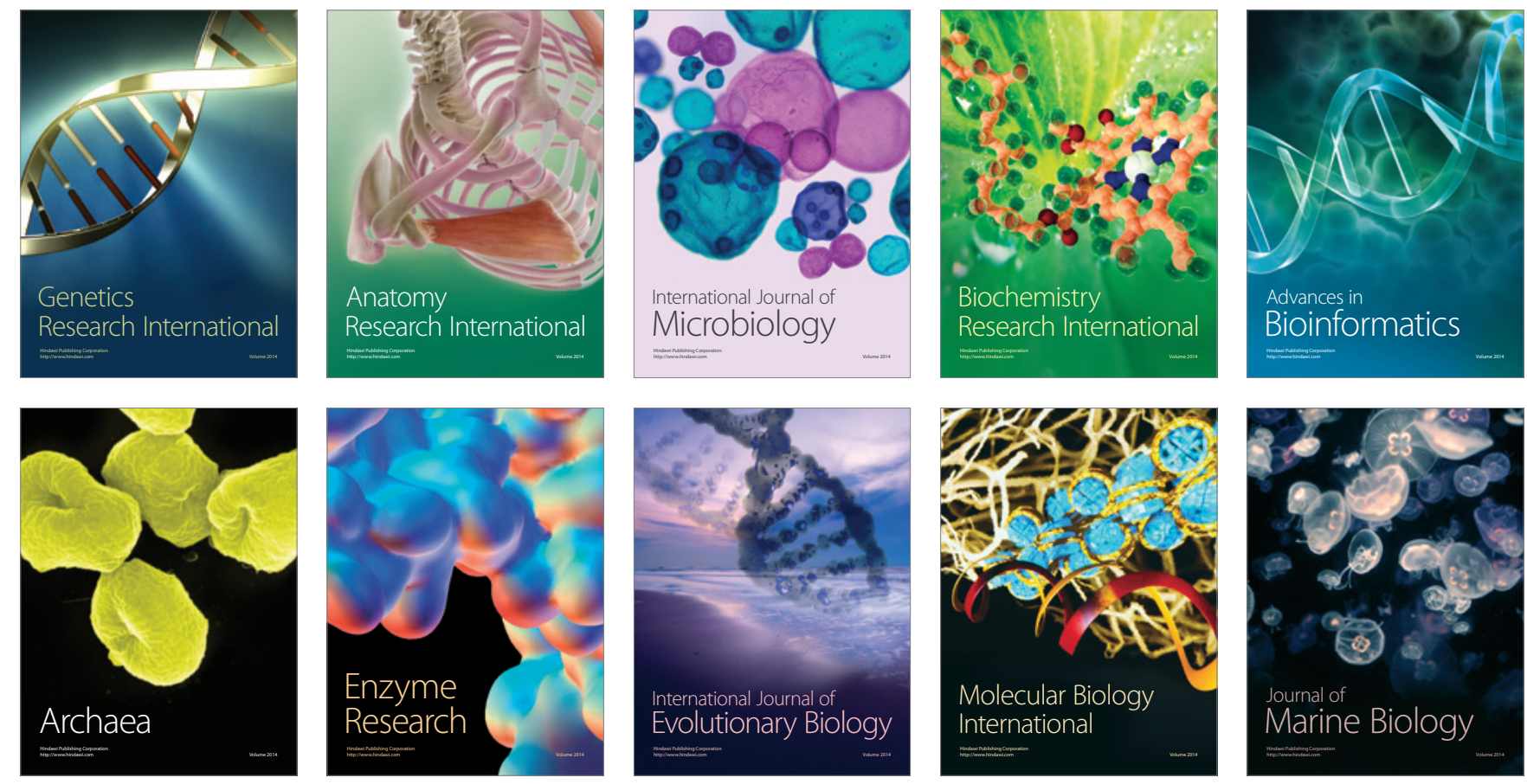